\title{
Yield and Quality of Malt Barley (Hordeum vulgare L.) in Response to Special Liquid Fertilizer (Trafos Synergy) Application in the Central Highlands of Ethiopia
}

\author{
Girma Chala $^{1} \quad$ Zeleke Obsa $^{1} \quad$ Emenu Jembere $^{2}$ \\ 1.Holeta Agricultural Research Center, EIAR, P.O.Box.31 \\ 2.Chemtex Trade Corp Company Country Coordinator
}

\begin{abstract}
Fertilizer application requirement to crops varies from location to location due to several factors. Thus, there is a need to evaluate response of yield and quality of malt barley to liquid fertilizer applications. Accordingly, an experiment was conducted to evaluate different dose of liquid fertilizer applications on yield and yield components of malt barley at Welmera (Holeta and Telecho) and Ejere (Cheri) districts during 2016 and 2017 main cropping season. The experiment was laid out in randomized complete block design with four replications. The treatments were different doses of Trafos synergy with the recommended NP, that is, $0,100 \% \mathrm{NP}, 100 \% \mathrm{NP}+$ Trafos synergy $4 \mathrm{~L} / \mathrm{ha}, 100 \% \mathrm{NP}+$ Trafos synergy $2 \mathrm{~L} /$ ha and $100 \% \mathrm{NP}+$ Trafos synergy $6 \mathrm{~L} / \mathrm{ha}$ ). Applications of recommended NP and Trafos synergy liquid nutrient sources in combination had a significant $(\mathrm{p}<0.05)$ effect on grain and biomass yield of malt barley. The highest grain yield $(3251.1 \mathrm{~kg} / \mathrm{ha})$ was obtained from the application of $100 \%$ $\mathrm{NP}+$ Trafos synergy $6 \mathrm{~L} / \mathrm{ha}$ ) at Cheri. Based on economic analysis, application of $100 \%$ recommended NP with Trafos synergy $4 \mathrm{~L} /$ ha fertilizer at HARC and Cheri site indicates promising for barley production on yield and grain quality.
\end{abstract}

Keywords: Grain quality, Trafos synergy, protein content

DOI: $10.7176 / \mathrm{JBAH} / 9-3-07$

\section{INTRODUCTION}

Barley (Hordeum vulgare L.) is one of the most important, economically valuable and widely used cereal crops. One source of income could be growing malting barley, which has dependable local buyers in the country (Agegnehu et al. 2011). This crop is used for preparing traditional food and beverage consumptions (Araya et al, 2011; Kemelew and Alemayehu, 2011). In the highlands of Ethiopia, farmers practice malt barley production systems were poor as dual purpose crops. In Ethiopia, barley production is highly concentrated in Oromia National Regional State with total area coverage of 454,662.78 hectares and total annual production of about 1.09 million tonnes, whereas the mean barley productivity was around 2.4 tonnes ha $^{-1}$ in main cropping season (CSA, 2017). The most important factors that reduce yield of barley in Ethiopia are poor soil fertility status, lack of special liquid fertilizer, poor crop management practices, and limited availability of improved varieties is among the most important constraints that threaten barley production in Ethiopia (Shiferaw and Anteneh ,2014). Trade corp's range of differentiated formulas is highly concentrated in micro, macronutrients and bio stimulants. This range is developed to meet specific needs of crops which influence quality, such as the protein content, sugar level, photosynthetic activity, etc according to the supplier blogger. It also provides a complete improvement of soil fertility. Moreover, it is easy to use and believed that it is safe to people and the environment. Liquid Chemical fertilizer usage by malt barley producers in Ethiopia is not practiced yet. Hence, it is a significant to evaluate Trade corp products as new fertilizer for malt barley production under rain fed condition. On behalf of these motivations, special liquid fertilizer (Trafos synergy) is applied to improve grain yield and grain quality of malt barley. Therefore, the objective of this study was to evaluate the response of yield and quality of malt barley to liquid fertilizer (Trafos synergy) applications.

\section{MATERIALS AND METHODS}

Description of the Experimental Site

The experiment was conducted during the 2016 and 2017 main cropping season at Welmera (Holeta and Telecho sites) and Ejere (Cheri sites) Districts in West Showa Zone, Oromia National Regional State. The study sites were located in the highlands of West Shewa zone between $09^{\circ} 00^{\prime} 3 " \mathrm{~N}$ latitude and $38^{\circ} 0{ }^{\prime} 20^{\prime \prime}$ E longitude and at an altitude of about 2400 meter above sea level (masl). The rainfall is bimodal with average annual rainfall of 1041.4 $\mathrm{mm}$, about $85 \%$ of which is received from June to September and the rest from January to May. The average minimum and maximum air temperature is 6.7 and $21.7{ }^{\circ} \mathrm{c}$ respectively and with relative humidity of $58.7 \%$ ( HARC, 2016 and 2017). The environments are seasonally humid and the major soil type of the trial sites is Eutric Nitisols (FAO classification).

Experimental Treatments, Design and Procedure

Grain yield and quality response of malt barley to special liquid fertilizer (Trafos synergy) experiment was 
conducted in major malt barley growing areas in West Showa Zone for two years (2016 and 2017). The experiment was designed in RCBD with four replications and consisting of different doses of Trafos synergy with recommended NP $(0,100 \% \mathrm{NP}, 100 \% \mathrm{NP}+$ Trafos synergy $4 \mathrm{~L} / \mathrm{ha}, 100 \% \mathrm{NP}+$ Trafos synergy $2 \mathrm{~L} / \mathrm{ha}$ and $100 \%$ $\mathrm{NP}+$ Trafos synergy $6 \mathrm{~L} / \mathrm{ha}$ ). The test crop was sown with row to row spacing of $20 \mathrm{~cm}$ comprising a total of 20 rows per plot in which a seed rate of $125 \mathrm{~kg} \mathrm{~kg} / \mathrm{ha}$ was maintained. Phosphorus was applied to all plots uniformly at the rate of $46 \mathrm{~kg} \mathrm{P}_{2} \mathrm{O}_{5} \mathrm{~kg} / \mathrm{ha}$ as triple super phosphate (TSP) at planting. Urea as $\mathrm{N}$ source was applied at the rate of $46 \mathrm{~kg} \mathrm{~N} \mathrm{kg/ha.} \mathrm{Split} \mathrm{application} \mathrm{of} \mathrm{nitrogen} \mathrm{was} \mathrm{used.} \mathrm{Similarly,} \mathrm{Trafos} \mathrm{synergy} \mathrm{fertilizer} \mathrm{were} \mathrm{applied} \mathrm{on}$ 35 days after planting, and then the recommended doses for liquid fertilizers $(2,4$ and $6 \mathrm{~L} / \mathrm{ha})$ were applied more than six times with 20 days intervals.

Soil Sample and Analysis

Composite surface soil samples were collected from experimental fields $(0-20 \mathrm{~cm}$ depth) before and after harvesting from each plot and then composited by replication to obtain one representative sample per treatment. Samples collected during both times were then analyzed for the determinations of soil $\mathrm{pH}$, total organic carbon (OC), total N, available P. Soil particle size distribution/texture/ was determined using the Bouyoucos hydrometer method (Bouyoucos, 1962). The $\mathrm{pH}$ of the soil was measured from suspension of 1:2.5 (weight/ volume) soil to water ratio using a glass electrode attached to digital $\mathrm{pH}$ meter (Page, 1982). Soil organic matter was determined by wet oxidation method (Walkely and Black, 1934). Total nitrogen was determined using Kjeldahl method (Jackson, 1967) and available phosphorus was determined using the Bray II method (Bray and Kurtz, 1945). Cation exchange capacity (CEC) was measured after saturating the soil with $1 \mathrm{~N}$ ammonium acetate $\left(\mathrm{NH}_{4} \mathrm{OAC}\right)(\mathrm{Chapman}$, 1965).

\section{Data collection and analysis}

Biomass yield and grain yield were collected as yield parameters of malt barley. Grain yield $\left(\mathrm{kg} \mathrm{ha}^{-1}\right)$ was recorded in six central rows in each plot by considering net plot area and converting into $\mathrm{kg} \mathrm{ha}^{-1}$ after the grams are adjusted to $12.5 \%$ moisture. Biomass yield $\left(\mathrm{kg} \mathrm{ha}^{-1}\right)$ was obtained by weighing above ground dry matter of plant (straw and grain) in central rows in each plot and converting into $\mathrm{kg} \mathrm{ha}^{-1}$.

\section{Grain quality parameters}

Thousand grain weight (TGW) was counted by grain counter machine and the thousand counted grain was weighed and taken as thousand grain weight. Hectoliter weight (HLW) was determined on dockage free samples using a standard laboratory hectoliter weight apparatus and moisture grain content $(\%)$ was measured by grain analysis computer (GAC) (AACC, 2000) method. Grain protein content (GPC \%) was determined by multiplying grain $\mathrm{N}$ percent by 5.83 , i.e. Grain protein $(\%)=\mathrm{N} \%$ x 5.83 (AACC, 2000). Germination energy was determined by taking one hundred barley grains were spread on wetted ( $4 \mathrm{ml}$ distilled water) filter paper lined on Petri dishes $(90 \mathrm{~mm})$ and allowed to germinate at nearly $100 \%$ relative humidity set at a temperature of $16^{\circ} \mathrm{C}$ germination cabinet for 3 days (Bam et al., 2006) method 3.6.

\section{Statistical analysis}

The collected data was subjected to statistical analysis using SAS software, version 9.0 (SAS, 2004). Significant differences between and/or among treatments was separated by Least Significant Differences (LSD) test. Interpretations were done following the procedures described by Gomez and Gomez (1984)

\section{Economic feasibility analysis}

The mean grain yield data were reduced by $10 \%$ to adjust the yield to the farmers' management conditions and subjected to partial budget analysis (CIMMYT, 1988). The cost of fertilizer was considered as a variable cost for the economic analysis. The cost varied for each treatment and treatments were ranked in order of ascending variable cost. Dominance analysis was used to eliminate those treatments which cost more, but which produced a lower net benefit, than the next lowest-cost treatment. The marginal rate of return (MRR) was calculated for each non dominated treatment and a minimum acceptable MRR of 100\% was assumed (CIMMYT, 1988). Two years average market grain price of malt barley (12 ETB $/ \mathrm{kg}$ ), farm-gate price of N and P fertilizers (12 and $15 \mathrm{ETB} / \mathrm{kg})$ respectively, price of Trafos synergy liquid fertilizer 65ETB/L were used.

\section{RESULTS AND DISCUSSION}

\section{Effects of special liquid (Trafos synergy) fertilization on soil chemical properties}

The results of the selected physio-chemical properties of the soils of the experimental sites, taken after harvesting are presented in Table 3 . The soil textural class was dominated by clay $(72 \%)$, silt $(18.25 \%)$ and sand $(9.75 \%)$ for HARC, while for Cheri clay (73.4\%), silt (19.65\%) and sand (6.55\%), categorized under clay soil for both sites. 
Table: 3. The Trafos synergy liquid fertilizer application on soil chemical properties analyzed samples after harvest of the crops

\begin{tabular}{|c|c|c|c|c|c|c|c|c|c|c|}
\hline \multirow{2}{*}{ 。. } & \multirow[b]{2}{*}{ Treatment } & \multicolumn{9}{|c|}{ Soil phsico-Chemical Properties } \\
\hline & & $\begin{array}{l}\text { Clay } \\
(\%)\end{array}$ & $\begin{array}{l}\text { Silt } \\
(\%)\end{array}$ & $\begin{array}{l}\text { Sand } \\
(\%)\end{array}$ & $\begin{array}{l}\text { Textural } \\
\text { class }\end{array}$ & $\begin{array}{l}\text { pH } \\
\left(\mathrm{H}_{2} 0\right)\end{array}$ & $\begin{array}{l}\text { TN } \\
(\%)\end{array}$ & $\begin{array}{l}\text { CEC } \\
\mathrm{Cmol}_{\mathrm{c}} \mathrm{kg}^{-1}\end{array}$ & $\begin{array}{l}\mathrm{OC} \\
(\%)\end{array}$ & $\begin{array}{l}\text { Av.P } \\
(\mathrm{ppm})\end{array}$ \\
\hline \multirow{5}{*}{ 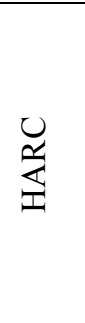 } & 0 & 72.5 & 21.25 & 6.25 & Clay & 5.70 & 0.12 & 27.1 & 1.82 & 13.24 \\
\hline & RNP $100 \%$ & 72.5 & 16.25 & 11.25 & Clay & 5.75 & 0.13 & 24.64 & 1.82 & 12.32 \\
\hline & $\begin{array}{l}100 \% \text { RNP + } \\
4 \mathrm{~L} / \mathrm{ha}\end{array}$ & 70 & 18.75 & 11.25 & Clay & 5.68 & 0.14 & 29.3 & 1.78 & 11.79 \\
\hline & $\begin{array}{l}100 \% \text { RNP + } \\
2 \mathrm{~L} / \mathrm{ha}\end{array}$ & 72.5 & 16.25 & 11.25 & Clay & 5.60 & 0.14 & 30.32 & 1.74 & 12.11 \\
\hline & $\begin{array}{l}100 \% \mathrm{RNP}+ \\
6 \mathrm{~L} / \mathrm{ha}\end{array}$ & 72.5 & 18.75 & 8.75 & Clay & 5.62 & 0.24 & 30.92 & 1.70 & 12.52 \\
\hline \multirow{5}{*}{ 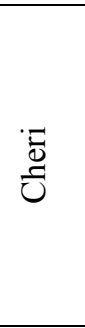 } & 0 & 73.0 & 21.25 & 3.75 & Clay & 4.65 & 0.1 & 26.72 & 1.74 & 11.29 \\
\hline & $100 \%$ RNP & 73.5 & 18.75 & 7.75 & Clay & 4.63 & 0.14 & 26.92 & 1.90 & 10.79 \\
\hline & $\begin{array}{l}100 \% \text { RNP + } \\
4 \mathrm{~L} / \mathrm{ha}\end{array}$ & 72.5 & 21.25 & 6.25 & Clay & 4.66 & 0.15 & 28.96 & 1.78 & 11.78 \\
\hline & $\begin{array}{c}100 \% \mathrm{RNP}+ \\
2 \mathrm{~L} / \mathrm{ha}\end{array}$ & 73.5 & 18.25 & 8.25 & Clay & 4.75 & 0.16 & 28.7 & 1.74 & 12.13 \\
\hline & $\begin{array}{l}100 \% \text { RNP + } \\
6 \mathrm{~L} / \mathrm{ha}\end{array}$ & 74.5 & 18.75 & 6.75 & Clay & 4.62 & 0.24 & 30.92 & 1.70 & 12.52 \\
\hline
\end{tabular}

$\overline{\mathrm{CL}}=$ Clay, $\mathrm{CEC}=$ Cation exchange capacity, $\mathrm{OC}=$ Organic carbon, $\mathrm{TN}=$ Total nitrogen, $\mathrm{Av} . \mathrm{P}=$ Available phosphorus. $\mathrm{RNP}=$ recommended $\mathrm{NP}$

At HARC the soil $\mathrm{pH}(\mathrm{H} 2 \mathrm{O})$ was 5.67 which is moderately acidic in its reaction; for Cheri the soil $\mathrm{pH}(\mathrm{H} 2 \mathrm{O})$ was 4.66 itis fall in strongly acidic which is similarly with Getachew and Sommer, 2000. The total N contents of soils after harvest were $0.15 \%$ (HARC) and $0.16 \%$ (Cheri), respectively. The soil organic carbon content was $1.76 \%$ for HARC and $1.77 \%$ for Cheri which means they are ranged in medium level for both sites and the result is agreement with Zelleke et al., (2010). The cation exchange capacity of the experimental study area was 28.46 $\mathrm{cmolckg}^{-1}, 28.44 \mathrm{cmolckg}^{-1}$, respectively for HARC and Cheri. The available phosphorus content of the experimental area for HARC and Cheri was $12.39 \mathrm{ppm}$, and $11.7 \mathrm{ppm}$, respectively. Thus, soil fertility status is sub-optimal for the production of barley.

Response of malt barley to Trafos Synergy liquid fertilizer.

The effect of trafos synergy liquid fertilizer on grain yield, pooled over the two cropping years, is presented in Table 4. This study clearly indicated that, productivity of malt barley was significantly affected by different dose of Trafos synergy and NP applied.

Table: 4. over years (2016 and 2017) combined analysis to response of Trafos synergy liquid fertilizer on malt barley grain and biomass yield

\begin{tabular}{lllllll}
\hline \multirow{2}{*}{ Treatments } & \multicolumn{2}{l}{ Grain yield (kg/ha) } & \multicolumn{3}{c}{ Biomass yield(kg/ha) } \\
\cline { 2 - 7 } & $\begin{array}{l}\text { Site1 } \\
\text { (HARC) }\end{array}$ & $\begin{array}{l}\text { Site2 } \\
(\text { Cheri) }\end{array}$ & $\begin{array}{l}\text { Site3 } \\
\text { (Telecho) }\end{array}$ & $\begin{array}{l}\text { Site1 } \\
\text { (HARC) }\end{array}$ & $\begin{array}{l}\text { Site2 } \\
\text { (Cheri) }\end{array}$ & $\begin{array}{l}\text { Site3 } \\
\text { (Telecho) }\end{array}$ \\
\hline Negative control & 2330.6 & $1738.65^{\mathrm{b}}$ & $1347.7^{\mathrm{b}}$ & $7743.1^{\mathrm{b}}$ & $7925.2^{\mathrm{b}}$ & 4268.9 \\
$100 \%$ RNP & 2695.0 & $3082.9^{\mathrm{a}}$ & $1976.9^{\mathrm{a}}$ & $8949.7^{\mathrm{a}}$ & $10171.9^{\mathrm{a}}$ & 5771.0 \\
$100 \%$ RNP + Trafos synergy 4L/ha & 3010.4 & $2713.1^{\mathrm{ab}}$ & $1773.2^{\mathrm{ab}}$ & $9567.8^{\mathrm{a}}$ & $10243^{\mathrm{a}}$ & 5673.5 \\
$100 \%$ RNP + Trafos synergy 2L/ha & 2731.0 & $2649.1^{\mathrm{ab}}$ & $2211.6^{\mathrm{a}}$ & $9078.2^{\mathrm{a}}$ & $10067.9^{\mathrm{a}}$ & 7206.4 \\
$100 \%$ RNP + Trafos synergy 6L/ha & 3067.5 & $3251.1^{\mathrm{a}}$ & $2218.4^{\mathrm{a}}$ & $9081.6^{\mathrm{a}}$ & $11007^{\mathrm{a}}$ & 6856.2 \\
\hline LSD (5\%) & NS & 988.2 & 406.2 & 427.5 & 782.6 & NS \\
CV (\%) & 14.95 & 18.2 & 21.5 & 8.6 & 17.2 & 16.4 \\
\hline
\end{tabular}

Thus, applications of recommended NP and Trafos synergy liquid nutrient sources in combination had a significant $(\mathrm{p}<0.05)$ effect on grain and biomass yield of malt barley. The application of recommended rates of NP with $6 \mathrm{~L} /$ ha Trafos-synergy increased malt barley grain yield by $13.8 \%$ at HARC, $5.5 \%$ at Cheri and $12.2 \%$ at Telecho when compared with standard check control (100\% RNP). The biomass yield of malt barley was significantly influenced by the application of Trafos synergy. The application of recommended rates of NP with 4 L/ha Trafos-synergy increased biomass yield by $6.9 \%$ at HARC, and application of recommended rates of NP with $6 \mathrm{~L} /$ ha Trafos-synergy resulted in biomass yield advantage of $8.2 \%$ at Cheri when compared with standard check control.

Grain Quality as affected by liquid fertilizer application

Hectoliter weight had a linear and positive response to Trafos synergy liquid fertilizer. The highest Hectoliter weight $\left(68.42 \mathrm{~kg} \mathrm{hl}^{-1}\right)$ was recorded at application of 100\% RNP + Trafo synergy $4 \mathrm{~L} / \mathrm{ha}$ and the lowest $(64.18 \mathrm{~kg}$ 
$\mathrm{hl}^{-1}$ ) hectoliter weight was recorded from negative control treatment (Table 5). The acceptable test weights (hectoliter weight) for barley are in the range 66.1-72.8kg hl-1 (Rick et al., 2014). While, the highest (13.23\%) grain protein content was recorded on $100 \% \mathrm{RNP}+$ Trafo synergy $6 \mathrm{~L} / \mathrm{ha}$ and the lowest $(10.46 \%)$ grain protein from negative control treatment and the highest germination energy $(96.86 \%)$ value was obtained from negative control treatments, while the lowest $(94.11 \%$ ) was obtained from the application of $100 \%$ RNP + Trafo synergy 6 L/ha .

Table: 5. Effect of Trafo Synergy liquid fertilizer on malt barley quality parameter

\begin{tabular}{lcccc}
\hline Applied N rate (kg/ha) & $\begin{array}{c}\text { Hectoliter } \\
\text { weight (kg/hl) }\end{array}$ & $\begin{array}{c}\text { Grain protein } \\
\text { content (\%) }\end{array}$ & $\begin{array}{c}\text { Germination } \\
\text { energy (\%) }\end{array}$ & $\begin{array}{c}\text { Moisture } \\
\text { Contents (\%) }\end{array}$ \\
\hline Negative control & 64.18 & 10.46 & 96.86 & 12.64 \\
$100 \%$ RNP & 67.14 & 11.48 & 95.42 & 12.79 \\
$100 \%$ RNP + Trafos synergy 4 L/ha & 68.42 & 13.04 & 94.88 & 12.83 \\
$100 \%$ RNP + Trafos synergy 2 L/ha & 68.02 & 11.27 & 95.14 & 12.42 \\
$100 \%$ RNP + Trafos synergy 6 L/ha & 68.19 & 13.23 & 94.11 & 12.88 \\
\hline
\end{tabular}

On the other hand, as protein content of malt barley increases, as Trafos synergy fertilizer was increased. Similar research findings with many authors (Bremer, 2004; McKenzie et al., 2005; Shiferaw and Anteneh, 2014) reported that with low available nutrient soil, malt barley responds well to applied fertilizer, showing increases in both yield and protein content. However, too much fertilizer especially nitrogen can increase protein beyond levels set by the maltsters. This increase in protein may increase steep times, cause uneven water uptake during steeping, make germination more erratic/not uniform, create undesirable qualities in the malt, increased malt loss due to abnormal growth, excessive enzymatic activity, low extract yield, excessive nitrogenous compounds in the wort during brewing and chill haze formation in beer (Johnston et al., 2007). Regards to grain moisture levels need to be low enough to inactivate the enzymes involved in seed germination as well as to prevent heat damage and the growth of disease microorganisms. Fox et al. (2003) reported that the maximum reasonable industrial specification of malt barley moisture content for safe storage is $12.5 \%$, whereas, the EBC standard, a moisture content of 12$13.5 \%$ is accepted.

\section{Economic feasibility of Trafos synergy fertilizer application}

Application of Trafos synergy liquid fertilizer 4L/ha with 100\% Recommended NP fertilizer indicated that the highest marginal rate return of $2414.2 \%$ at HARC site (Table 6) and at Cheri and Telecho study site $100 \%$ Recommended NP plus Trafos synergy 6L/ha fertilizer provided the highest marginal rate of the return (MRR) of $4742 \%$ (Table 7) and 3907.3\%(Table 8) were recorded, respectively. Whereas, based on the economical recommendation of CIMMYT (1988) which stated that farmers should be willing to change from one treatment to another if the marginal rate of return of that change is greater than the minimum acceptable rate of return.

Table 6: Partial budget and dominance analyses of Trafos synergy fertilizer on malt barley HARC on station

\begin{tabular}{lllllll}
\hline \multicolumn{1}{c}{ Treatment } & $\begin{array}{l}\mathrm{GY} \\
\mathrm{kg} / \mathrm{ha}\end{array}$ & \multirow{2}{*}{ AD GY kg/ha } & $\begin{array}{l}\text { TVC } \\
(\mathrm{ETB})\end{array}$ & $\begin{array}{l}\text { Gross Benefit } \\
(\mathrm{ETB})\end{array}$ & $\begin{array}{l}\text { Net Benefit } \\
(\mathrm{ETB})\end{array}$ & $\begin{array}{l}\text { MRR } \\
(\%)\end{array}$ \\
\hline $\begin{array}{l}\text { Negative control } \\
\text { 100\% RNP }\end{array}$ & 2330.6 & 2097.5 & 12 & 25170.5 & 25158.5 & 0.0 \\
$\begin{array}{l}\text { 100\% RNP + Trafos synergy } 2 \\
\text { L/ha }\end{array}$ & 2695 & 2425.5 & 3162 & 29106 & 25944.0 & 24.9 \\
$\begin{array}{l}\text { 100\% RNP + Trafos synergy } 4 \\
\text { /ha }\end{array}$ & 3010.4 & 2457.9 & 3582 & 29494.8 & 25912.8 & $\mathrm{D}$ \\
$\begin{array}{l}\text { 100\% RNP + Trafos synergy 6 } \\
\text { L/ha }\end{array}$ & 3067.5 & 2760.8 & 3822 & 33129 & 29307.0 & 414.4 \\
\hline
\end{tabular}


Table 7: Partial budget and dominance analyses of Trafos synergy fertilizer on malt barley at Cheri

\begin{tabular}{lllllll}
\hline Treatment & GY kg/ha & AD GY kg/ha & $\begin{array}{l}\text { TVC } \\
\text { (ETB) }\end{array}$ & $\begin{array}{l}\text { Gross } \\
\text { Benefit } \\
\text { (ETB) }\end{array}$ & $\begin{array}{l}\text { Net Benefit } \\
\text { (ETB) }\end{array}$ & MRR (\%) \\
\hline $\begin{array}{l}\text { Neg control } \\
\text { 100\% RNP }\end{array}$ & 1738.7 & 1564.8 & 12 & 18777.4 & 18765.4 & 0.0 \\
$\begin{array}{l}100 \% \text { RNP + Trafos synergy } \\
\text { L/ha }\end{array}$ & 3083.0 & 26474.7 & 3150 & 33295.9 & 30145.9 & 362.7 \\
$\begin{array}{l}\text { 10\% RNP + Trafos synergy } 4 \\
\text { L/ha }\end{array}$ & 2713.1 & 2384.2 & 3570 & 28610.3 & 25040.3 & D \\
$\begin{array}{l}100 \% \text { RNP + Trafos synergy } 6 \\
\text { L/ha }\end{array}$ & 3251.1 & 2926.0 & 3810 & 35111.9 & 31301.9 & 4742.0 \\
\hline
\end{tabular}

Where, price of Trafos synergy liquid fertilizer $=65 \mathrm{ETB} / \mathrm{L}$, price of N $(12 \mathrm{ETB} / \mathrm{kg})$ and $\mathrm{P}(15 \mathrm{ETB} / \mathrm{kg})$ fertilizers, respectively, $\mathrm{ETB}=$ Ethiopian Birr, $\mathrm{TVC}=$ total variable cost, $\mathrm{GY}=$ grain yield, $\mathrm{AD} \mathrm{GY}=$ Adjusted grain yield Therefore, it would be desirable for producer in the study area application of $100 \%$ Recommended NP plus $4 \mathrm{~L} / \mathrm{ha}$ Trafos synergy at HARC station (Table 6) for better barley production but at Cheri (Table 7) and Telecho(Table 8) study sites application of $100 \%$ recommended NP out-of-the-way is economical.

Table 8: Partial budget and dominance analyses of Trafos synergy fertilizer on malt barley at Telecho

\begin{tabular}{lllllll}
\hline \multicolumn{1}{c}{ Treatment } & \multirow{2}{*}{ GY kg/ha } & AD GY kg/ha & $\begin{array}{c}\text { TVC } \\
\text { (ETB) }\end{array}$ & $\begin{array}{c}\text { Gross Benefit } \\
\text { (ETB) }\end{array}$ & $\begin{array}{c}\text { Net Benefit } \\
\text { (ETB) }\end{array}$ & $\begin{array}{c}\text { MRR } \\
(\%)\end{array}$ \\
\hline $\begin{array}{l}\text { Negative control } \\
\text { 100\% RNP }\end{array}$ & 1347.7 & 1212.9 & 12 & 14555.2 & 14543.2 & 0.0 \\
$\begin{array}{l}\text { 10\%\% RNP + Trafos synergy 2 } \\
\text { L/ha }\end{array}$ & 1976.9 & 1779.3 & 3162 & 21351.1 & 18189.1 & 115.7 \\
$\begin{array}{l}\text { 100\% RNP + Trafos synergy 4 } \\
\text { L/ha }\end{array}$ & 1773.2 & 1595.9 & 3702 & 19150.0 & 15448.0 & D \\
$\begin{array}{l}\text { 10\% RNP + Trafos synergy 6 6 } 6 \\
\text { L/ha }\end{array}$ & 2218.4 & 1990.5 & 3582 & 23885.8 & 20303.8 & 503.5 \\
\hline
\end{tabular}

\section{CONCLUSION AND RECOMMENDATION}

Chemical fertilizer put forward nutrients which are readily soluble in soil solution and thereby immediately available to plants. The aim of this study was to increase yield and yield components of malt barley production using appropriate nutrient form and, rates .Application of different dose of Trafos synergy liquid fertilizers was not significantly affect grain and biomass yield when compared to $100 \%$ recommended NP treatment, but there was significance difference observed on grain and biomass yield, when compared to with negative control (without fertilizer) treatment. With regard to the protein content, all the Trafos synergy liquid fertilizer doses slightly increases the protein content of the malt barely. However, the protein content of the malt barely is considered to be superior when it is lower than $12 \%$, recommended nitrogen and phosphorus fertilizers being the best. The result of the current study showed that grain protein content within the acceptable range, except $(100 \%$ RNP + Trafo synergy 4 and $6 \mathrm{~L} / \mathrm{ha}$ ) (Table 11). Accordingly, application of $100 \%$ Recommended NP plus $4 \mathrm{~L} / \mathrm{ha}$ Trafos synergy fertilizer at HARC station (Table 6) was encouraged for improvement of yield and quality.

\section{ACKNOWLEDGMENTS}

We would like to thank the Chemtex Trade Corp Company for the provision of the products as well as financial support and would like to express appreciation to Inorganic soil fertility program team of Holeta Agricultural Research Centre for their technical assistance during the execution of the experiments under field condition and services of soil analysis

\section{REFERENCE}

AACC (American Association Cereal Chemists). 2000. Approved Methods of the American Association Cereal Chemists. American Association of Cereal Chemists, Inc., St. Paul, Minnesota.

Abdenna Deressa, Bikila Bote and Hirpa Legesse. 2013. Evaluation of Soil Cations in Agricultural Soils of East Wollega Zone in South Western Ethiopia. Science technology arts Research Journal, 2(1): 10-17

Araya Alemie, Solomon Habtu, Mitiku Haile, Sisay F. and Tadesse Dejenie. 2011. Determination of Local Barley (Hordeum Vulgare) Crop Coefficient and Comparativ Assessment of Water Productivity for Crops Grown Under the Present Pond Water in Tigray, Northern Ethiopia

Bam forth, C., and A. Barclay. 2006. Malting technology and the uses of malt. Barley Chemistry and Technology, University of Minnesota, USA. 297-354. 
Bouyoucos, J. 1962. Hydrometer method improved for making particle size analysis of soil. Agronomy Journals, 54:464-465.

Chapman, H. D. 1965. Cation exchange capacity by ammonium saturation. 9: Inc 891-901. Black, C.A., L.E. Ensminger and Clark F.E. (Eds.). Method of soil analysis. American Society of Agronomy, Madison Wisconsin, USA.

CIMMYT (International Center of Wheat and Maize Improvement).1988. From agronomic data to farmer recommendations: An economic training manual. Revised Edition. Mexico, D.F.

CSA (Central statistical agency) agricultural sample survey. 2017. Report on area and production of major crops (private peasant holdings, Meher season). Volume I, Statistical bulletin, Addis Ababa, Ethiopia, p10-12.

EQSA (Ethiopia Quality Standards Authority). 2006. Malting Barley Specification. Addis Ababa, Ethiopia. Ethiopia, 11-14 February, 1986.

Fox, G.P., Panozzo J.F., Li, C.D., Lance, R.C.M., Inkerman, P.A. and Henry, R.J. 2003. Molecular basis of barley quality. Australian Journal of Agricultural Research, 54: 1081-1101.

Getachew, A and Sommer, K. 2000. Optimization of the efficiency of phosphate fertilizers in acidic- ferralitic soils of the humid tropics. Ethiopian J. of Natu. Reso. 2: 63-77.

HARC (Holetta Agricultural Research Center).2016 / 2017. Agrometeorological data annual progress Report, Holeta, Ethiopia

Jackson, M.L. 1967. Soil Chemical Analysis. Prentice-Hall of India, New Delhi.

Johnston A, Murrel S, and Grant C. 2007. Nitrogen fertilizer management of malting barley: Impacts of crop and fertilizer nitrogen prices, 21-24.

Kemelew Muhe and Alemayehu Assefa. 2011. Diversity and Agronomic Potential of Barley (Hordeum vulgare L.) Landraces in Variable Production System, Ethiopia. World Journal of Agricultural Sciences, 7 (5): 599603

McKenzie RH, Middleton AB, and Bremer E. 2008. Fertilization, seeding date and seeding rate for malting barley yield and quality in southern Alberta. Canada Journal of Plant Sciences, 85: 603-614

Muluken Bentayehu. 2013. Study on malting barley genotypes under diverse agro ecologies of North Western Ethiopia. African Journal of Plant Science, 7(11): 548-557

Page, A.L. 1982. Methods of soil analysis. Part II: Chemical and microbiological properties.

Rick Graham, Ian Menz, Nick Moody and Neroli Graham, 2014. Western Australian malting barley varietal recommendations. Date: 11 Feb 2014.

SAS. 2004. SAS/STAT User's Guide, Version 9.0. SAS institute Inc., Cary, and NC.USA.

Shiferaw, B. and Anteneh, F. 2014. Lime and NPK Effect on Soil Acidity and Yield of Barely in different Acid Soils of Southern Region, Ethiopia. Intern. J. of Natu. Sci. Res. 2(7): 113-122.

Walkley, A. and Black I.A.1934. Estimation of soil organic carbon by the chromic acid titration method. Soil Science, 37: 29-38.

Zelleke, G, Agegnehu, G, Abera, D and Rashid, S. 2010. Fertilizer and Soil Fertility Potential in Ethiopia: Constraints and opportunities for enhancing the system.Addis Ababa: International Food Policy Research Institute. 